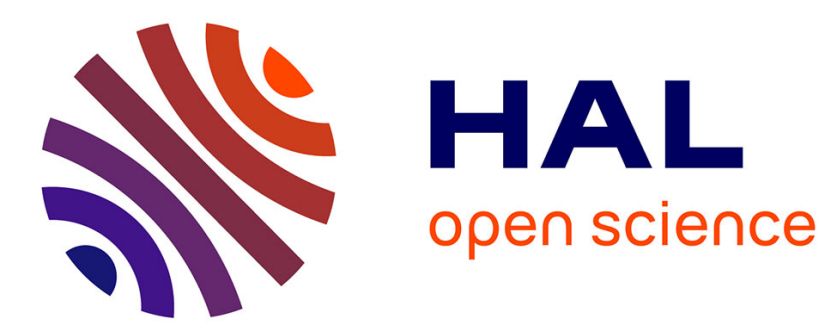

\title{
Similarities and Differences between Colicin and Filamentous Phage Uptake by Bacterial Cells
}

\author{
Denis Duché, Laetitia Houot
}

\section{To cite this version:}

Denis Duché, Laetitia Houot. Similarities and Differences between Colicin and Filamentous Phage Uptake by Bacterial Cells. EcoSal Plus, 2019, 8 (2), 10.1128/ecosalplus.ESP-0030-2018 . hal-02395622

\section{HAL Id: hal-02395622 \\ https://hal.science/hal-02395622}

Submitted on 31 Jan 2020

HAL is a multi-disciplinary open access archive for the deposit and dissemination of scientific research documents, whether they are published or not. The documents may come from teaching and research institutions in France or abroad, or from public or private research centers.
L'archive ouverte pluridisciplinaire HAL, est destinée au dépôt et à la diffusion de documents scientifiques de niveau recherche, publiés ou non, émanant des établissements d'enseignement et de recherche français ou étrangers, des laboratoires publics ou privés. 
1 Similarities and differences between colicin and filamentous phage uptake by bacterial

2 cells.

3

4 Denis Duché* and Laetitia Houot*

5

6 From the Laboratoire d'Ingénierie des Systèmes Macromoléculaires, UMR7255, Institut de

7 Microbiologie de la Méditerranée, Aix-Marseille Univ - CNRS, 31 Chemin Joseph Aiguier,

813402 Marseille Cedex 20, France

9

10 *To whom correspondence should be addressed: Laboratoire d'Ingénierie des Systèmes 11 Macromoléculaires, UMR7255, Institut de Microbiologie de la Méditerranée, Aix-Marseille 12 Univ - CNRS, 31 Chemin Joseph Aiguier, 13402 Marseille Cedex 20, France; Tel: +33 491164-663; Fax: +33 491712 124; E-mail: duche@imm.cnrs.fr and lhouot@imm.cnrs.fr

16 Abstract

17 Gram-negative bacteria have evolved a complex envelope to adapt and survive in a broad range of ecological niches. This physical barrier is the first line of defense against noxious compounds and viral particles called bacteriophages. Colicins are a family of bactericidal proteins produced by and toxic to Escherichia coli and closely related bacteria. Filamentous phages have a complex structure, composed of at least five capsid proteins assembled in a long thread-shaped particle that protect the viral DNA. Despite their difference in size and complexity, group A colicins and filamentous phages both parasitize multiprotein complexes of their sensitive host

24 for entry. They first bind to a receptor located at the surface of the target bacteria before specifically recruiting components of the Tol system to cross the outer membrane and find their 
way through the periplasm. The Tol system is thought to use the proton-motive force of the inner membrane to maintain outer membrane integrity during the life cycle of the cell. This review will describe the sequential docking mechanisms of group A colicins and filamentous phages during their uptake by their bacterial host, with a specific focus on the translocation step, promoted by interactions with the Tol system.

\section{Introduction}

The cell envelope of Gram-negative bacteria, such as Escherichia coli, is characterized by the presence of two membranes, the inner (IM) and outer (OM) membranes, separated by the periplasm and a thin layer of peptidoglycan (PG). This envelope is a formidable barrier against a myriad of harmful compounds, while simultaneously allowing the entry of nutrients necessary for cell survival. However, this barrier, like the "Maginot Line" in France during the Second World War, is not completely impenetrable and exogenous particles, including some toxins and viruses, can pierce it.

Colicins are plasmid-encoded toxins (40 to $80 \mathrm{kDa}$ ), produced by E. coli under conditions of stress, that allow the efficient killing of related bacteria competing for space and resources. The toxicity of colicins relies on various modes of action, including IM depolarization, the inhibition of PG synthesis, and the degradation of DNA or RNA of the target cell. Colicins can be classified into two groups, A and B, depending on whether they use the Tol or Ton protein complexes to cross the $\mathrm{OM}$ and translocate through the periplasm of their host (for a review, see 1)

Filamentous bacteriophages or Inoviridae are elongated viruses ( 7 by $\sim 800-2000 \mathrm{~nm}$ ) that must pierce the whole envelope to deliver their nucleic acid into the cytoplasm of the target cell to complete their life cycle. The virion particle consists of an assembly of the major coat 
protein $\mathrm{pVIII}$, capped with the adsorption protein $\mathrm{pIII}$ and minor coat proteins (pVI, $\mathrm{pVII}$ and pIX), encapsulating the circular single-stranded viral DNA. Among inoviruses, Ff coliphages have garnered particular scientific attention because of their extensive application in genetic engineering and phage display technology (reviewed in 2), along with the vibriophage CTX, which converts Vibrio cholerae to pathogenicity (3).

While colicins and phages are very different particles, their mode of uptake across the bacterial envelope shares both structural and functional similarities. They both use a multistep process that relies on the parasitism of structures produced by sensitive bacteria. Group A colicins and filamentous phages are first specifically recruited via an interaction with a bacterial surface receptor (reception step), followed by crossing of the OM and transport through the periplasm (translocation step). This step requires interactions with one or several proteins of the Tol system, a conserved macromolecular motor of the cell (4). This review describes the similarities and differences observed between the group A colicin and filamentous phage models of adsorption and translocation into their host and the role of cellular energy in these processes.

\section{Colicins and the Filamentous Phage Adsorption Protein pIII Show Similar Structural} Organization.

As for many toxins, colicins are organized into three structural domains that perform specific functions (Fig. 1A); the central domain (receptor domain, R) binds a specific bacterial $\mathrm{OM}$ protein, the $\mathrm{N}$-terminal domain (translocation, $\mathrm{T}$ domain) is required for colicin translocation across the $\mathrm{OM}$ and interacts with the Tol system, and the C-terminal domain encodes the toxic activity (5-10). The crystallographic structures of some colicins have highlighted two important features: long antiparallel coiled-coil $\alpha$-helices within the R-domain that separate this domain from the $\mathrm{T}$ and $\mathrm{C}$-domains and a disordered region within the $\mathrm{T}$ 
domain (11-14). Importantly, nuclease colicins are produced in a complex with an immunity protein, preventing their lethal action in the producing cell (Fig. 1B).

Filamentous phage infection is driven by three to five copies of the minor coat protein pIII (also called G3P), located at the tip of the particle $(2,15)$. As for colicins, phage pIII protein is organized into three functional domains, separated by two flexible regions $(16,17)$ (Fig. 1A). The central (N2) domain is responsible for adsorption to a pilus, whereas the N-terminal (N1) domain interacts with the Tol system. The pIII C-terminal domain anchors pIII to the phage particle and is required for DNA injection into the host. The structure of pIII-N1 and pIII-N1N2 has been solved for the Ff and CTX phages by crystallography and NMR studies (Fig. 1B) $(16,18-22)$

\section{Binding to the Primary Receptor and Crossing of the OM.}

The initial cellular reception of most group A colicins requires a high affinity OM protein receptor, such as BtuB for colicins A and E1 to E9 (Table1) (23-25). The structure of the colicin E3 and E2 R domain (135 residues) bound to BtuB has been solved $(26,27)$. In the current model of colicin uptake, the elongated helical coiled-coil R-domain binds BtuB with the $\mathrm{T}$ and $\mathrm{C}$ domains extending at a $45^{\circ}$ angle out over the OM. Then, the intrinsically disordered region of the T-domain, adjacent to the OM, searches for a more abundant second receptor (called "the translocator"), in this case OmpF, and crosses the OM through one of the OmpF pores, which are wide enough to accommodate unfolded peptides. This model is based on numerous experiments, such as occlusion of the OmpF channel in planar lipid bilayers by colicin T domains and isolation of an intact complex of colicin with BtuB and OmpF, confirmed by crystallization of colicin T-domain peptides within the OmpF pore (28-32). The resulting Colicin-BtuB-OmpF complex is called the "colicin OM translocon" (Fig. 2A). 

that extend from the cell surface as extracellular receptors (Table1). Adsorption of the phage to the pilus is dependent on pIII-N2, the central domain of the capsid protein pIII $(17,33)$. For Ff phages, $\mathrm{N} 2$ binding to the $E$. coli $\mathrm{F}$ pilus leads to conformational changes in pIII that unmask the TolA binding site on N1, allowing phage infection to proceed (34) (Fig. 2B). How these phages cross the $\mathrm{OM}$ to reach the periplasmic space is unknown, but they may follow pilus retraction through the pilus secretin that spans the OM (35-37). Interestingly, the reception step is not strictly required for phage infection, as phages can bypass the pilus to infect cells at low frequencies $(17,38,39)$. In the absence of the $\mathrm{F}$ pilus receptor, the addition of $\mathrm{CaCl}_{2}$ to the medium has been reported to enhance phage infection, possibly by neutralizing negative charges at the cell surface (38).

After the binding step, which allows specific targeting of the bacterial host, both group A colicins and filamentous phages parasitize a trans-envelope protein complex, the Tol system, to cross the periplasm. The Tol-system components required for this step can vary depending

114 on the group A colicin or phage involved (Table1).

\section{The Tol Macrocomplex: A Conserved Molecular Motor of the Bacterial Envelope} five proteins, TolQ, TolR, TolA, TolB, and Pal, which form a complex in the cell envelope.

119 TolQRA are IM proteins that interact via their trans-membrane (TM) segments to form an IM complex (41-44). TolQ is a polytopic protein with three TM segments, whereas TolA and TolR are bitopic proteins with a large periplasmic domain $(43,45-48)$. TolB is a periplasmic protein composed of two subdomains, called D1 and D2, in which D2 forms a six-bladed B-propeller $(49,50)$. Finally, Pal is a lipoprotein tethered to the OM via its N-terminal acylated residue, and

124 its C-terminal domain is free to interact with the peptidoglycan (PG) layer and TolB (51-55). 
125 Thus, TolB-Pal forms the OM complex of the Tol system and TolB competes with the PG to

126 bind Pal (56). The two Tol subcomplexes are transiently connected via the C-terminal domain 127 of TolA (called TolAIII), which interacts with both TolB-D1 and Pal (57-60). The TolQ-TolR 128 complex uses the proton motive force (PMF) to induce conformational changes in the 129 periplasmic domain of TolA, promoting the TolA-Pal interaction $(4,41,61)$. Thus, the Tol 130 system works as a molecular motor, using the PMF to form a link between PG and the inner 131 and outer membranes.

The Tol system has been reported to be essential in many bacterial species, whereas it 133 is dispensable in the E. coli K12 strain (62-66). In E. coli, deletion of any of the tol genes causes

134 a pleiotropic phenotype. Indeed, tol mutants are highly sensitive to detergents and some 135 antibiotics, they release periplasmic proteins into the extracellular medium and they form numerous OM vesicles (67-71). These phenotypes all suggest a potential role of the Tol system in the maintenance of $\mathrm{OM}$ integrity. This role can be partially explained by the involvement of the Tol complex in OM lipid homeostasis $(72,73)$. Finally, the Tol system has been described

139 to be involved in the late stage of the cell-division process, more precisely in OM invagination 140 during cell division $(62,74)$.

The Tol System Serves as a Versatile Import Machinery for Parasites and Toxins.

144 filamentous phages. Indeed, direct or indirect interactions of these particles with components 145 of the Tol complex have been described. When they reach the periplasmic space, most group 146 A colicins first recruit the $\beta$-propeller domain of TolB through their N-terminal T domain (50,

147 58, 75-77). Conversely, TolB is not required for phage uptake $(39,78)$. The affinity of ColE9 148 to TolB has been shown to be strong enough to competitively displace TolB from Pal $(77,79)$. 149 Structural data has shown that, in the presence of Pal, the N-terminal 12 residues of TolB, 
encompassing the TolA binding domain, are ordered and sequestered to the TolB surface, whereas these residues are disordered and accessible to TolA binding in the presence of the ColE9 T-domain $(79,80)$. Thus, in the presence of ColE9, TolB binds to TolAIII and the toxin can continue its translocation. Although this model can be applied to the other nuclease colicins, some results suggest that the mechanism for the recruitment of TolB by the pore-forming colicin A may be different. As ColA is unable to competitively displace TolB in the TolB-Pal complex, the model suggests that the toxin binds to free periplasmic TolB and then to TolAIII, for which it has a higher affinity (81) (Fig. 2A).

All group A colicins and filamentous bacteriophages studied to date require TolA for their transit into the periplasm (Table 1). Direct interaction between the TolAIII domain and the colicin $\mathrm{A}, \mathrm{E} 1, \mathrm{~N}$, and $\mathrm{K} \mathrm{T}$-domain has been shown by numerous in vivo and in vitro experiments (82-85). Similarly, the pIII protein at the tip of the phage particle is responsible for TolA binding $(19,22,86,87)$. The phage pIII-N1 and pIII-N2 domains have been reported to bind E. coli TolAIII and TolAII domains, respectively (88). No direct interaction has yet been observed between TolA and enzymatic colicins, even though tolA mutants are tolerant to these toxins.

Several studies indicate that TolA has diverse binding sites, which enable multiple interactions with other partners. First, point mutations or deletions in tolA differentially affect colicin import; some remain active, whereas others lose their ability to kill mutated strains (59, 89). Second, structural data have shown that the colicin A T-domain interacts with the convex site of TolAIII, whereas the phage Ff and IF1 pIII-N1 domain and colicin N T-domain bind to the concave side of TolAIII $(18,21,90-93)$ (Fig. 1B). In contrast to coliphage Ff, the vibriophage CTX pIII-N1 domain binds to the convex site of $V$. cholerae TolAIII (22). The role of the TolQ and TolR proteins in both phage and colicin uptake is less clear.

174 Although TolQ and TolR are necessary but not essential for phage infection $(39,94)$, both are 
175 absolutely required for the translocation of group A colicins (excepted ColE1). However, only

176 a few studies have reported a direct interaction between colicins and either TolQ or TolR. The

177 ColA and ColE3 T-domain has been shown to interact with TolR by cross-linking experiments

178 (95) and the interaction between the ColK T-domain with TolQ or TolR has been revealed by

179 coimmunoprecipitation (85). The final steps concerning the toxic effect of colicins and phage

180 DNA injection are not discussed here but are briefly summarized in Figure 2.

\section{Importance of Protein Structural Flexibility in Uptake Pathways.}

An interesting aspect of the current models of colicin uptake is that their T-domains are disordered and that they fold into an ordered structure upon binding to a Tol protein. This disorder-to-order transition could explain the ability of colicins to bind several target partners and progress through the periplasm.

Another important aspect in both colicin and phage translocation is the large-scale structural modification of the molecules during the process. First, studies have shown that colicins A and E2 remain bound to their receptor and the Tol machinery, whereas their C and

190 T domains are translocated $(96,97)$. Second, in vivo and in vitro experiments have shown that colicin A unfolds during its import into the cells $(98,99)$. This unfolding is triggered either by binding to the first ColE1 receptor, which is then propagated to the distal ends of the $\mathrm{T}$ and $\mathrm{C}$ domains of the toxin $(26,100)$, or it occurs after recruitment of the second receptor and

194 formation of the "colicin OM translocon" for ColE9 (101). Similarly, the extensive structural 195 modifications of coliphage pIII protein during initial binding to the F-pilus, followed by interaction with TolA in the periplasm, have been proposed to lead to the insertion of pIII-C into the IM of the host and the formation of a multimeric channel that allows phage DNA injection into the bacterial cytoplasm, concomitant with disassembly of the capsid by diffusion of the major coat protein pVIII in the membrane $(102,103)$. 
201 Energetics of Colicin and Filamentous Phage Uptake.

Despite the large number of publications on colicin and phage import, only a few studies have focused on the energetic aspect of this process. As discussed above, the Tol system use the IM PMF, by means of the TolQR motor, to power mechanisms involved in the maintenance of OM integrity and cell constriction. However, initial studies suggested that the Tol-dependent import of two pore-forming colicins, ColA and ColE1, is energy-independent $(104,105)$. These results were later confirmed by point-mutations introduced into the TolQR motor that affect the physiological function of the Tol system without preventing the killing action of pore-forming colicins. These mutations were called "discriminative mutations" (106, 107). Energy

210 requirements for the import of nuclease colicins appear to be different. It is clear that release of 211 the immunity protein from nuclease colicins in the external medium requires functional import machinery $(108,109)$. Intriguingly, the release of the ColE9 immunity protein was shown to be energy dependent (109), whereas strains harboring discriminative TolQR mutations remain

214 susceptible to ColE2 (107). Based on these divergent results, the question of the energy

215 requirement for the translocation of group A colicins is still open. For coliphages, experiments using arsenate or protonophores has led to the hypothesis that phage uptake may be dependent on both ATP and PMF, possibly for pilus retraction and phage particle transit through the periplasm, respectively $(110,111)$.

In summary, it is fascinating to observe that small toxins, such as colicins, and complex viral structures, such as filamentous phages, are shaped so as to use similar molecular mechanisms to pierce the envelope of their target cell. These include a sequential docking mechanism, the strict requirement for the hub protein TolA, and large-scale structural modifications of the proteins during their transit. Although some key steps in these processes 
225 have been well characterized, numerous questions are still unanswered concerning the 226 dynamics, sequence of events, and role of host-cell energy in the uptake of these 227 nanostructures.

228

229 Acknowledgements

230 We thank Roland Lloubes, Laure Journet, and Jean Peuplu for careful reading of the 231 manuscript. Work in the laboratory is supported by the Centre National de la Recherche 232 Scientifique (CNRS), the Aix-Marseille Univ., and funded by the Agence Nationale de la 233 Recherche (MEMOX, ANR-18-CE11-0027) 
1. Cascales E, Buchanan SK, Duché D, Kleanthous C, Lloubès R, Postle K, Riley

2. Rakonjac J, Bennett NJ, Spagnuolo J, Gagic D, Russel M. 2011. Filamentous bacteriophage: biology, phage display and nanotechnology applications. Curr Issues Mol Biol. 13:51-76.

3. Waldor MK, Mekalanos JJ. 1996. Lysogenic conversion by a filamentous phage encoding cholera toxin. Science. 272:1910-4.

4. Cascales E, Lloubès R, Sturgis JN. 2001. The TolQ-TolR proteins energize TolA and share homologies with the flagellar motor proteins MotA-MotB. Mol Microbiol. 42:795-807.

5. Baty D, Frenette M, Lloubès R, Géli V, Howard SP, Pattus F, and Lazdunski C. 1988. Functional domain of Colicin A. Mol Microbiol. 2: 807-11.

6. Dankert, JR, Uratani Y, Grabau C, Cramer WA, Hermodson M. 1982. On a domain structure of colicin E1. A COOH-terminal peptide fragment active in membrane depolarization. J Biol Chem. 257: 3857-63. affecting colicin E3 bactericidal activity. Mol Microbiol. 13: 82-5. 
8. Martinez C, Lazdunski C, Pattus F. 1983. Isolation, molecular and functional properties of the C-terminal domain of colicin A. EMBO J. 2: 1501-7

9. Ohno-Iwashita Y, Imahori K. 1980. Assignment of the functional loci in colicin E2 and E3 molecules by characterization of their proteolytic fragments. Biochemistry. 19: $652-9$

10. Ohno-Iwashita Y, Imahori K. 1982. Assignment of the functional loci in the colicin E1 molecule by characterization of its proteolytic fragments. $J$ Biol Chem.

11. Wiener M, Freymann D, Ghosh P, Stroud RM. 1997. Crystal structure of colicin Ia. Nature. 385: 461-4.

12. Vetter IR, Parker MW, Tucker AD, Lakey JH, Pattus F, Tsernoglou D. 1988. Crystal structure of a colicin N fragment suggests a model of toxicity. Structure. $\mathbf{6}$ : 863-74.

13. Soelaiman S, Jakes K, Wu N, Li C, Shoham M. 2001. Crystal structure of colicin E3: implications for cell entry and ribosome inactivation. Mol Cell. 8: 1053-62.

14. Deprez C, Blanchard L, Guerlesquin F, Gavioli M, Simorre JP, Lazdunski C, Marion D, Lloubès R. 2002. Macromolecular import into Escherichia coli: the TolA C-terminal domain changes conformation when interacting with the colicin A toxin. Biochemistry. 41:2589-98. 
15. Grant RA, Lin TC, Konigsberg W, Webster RE. 1981. Structure of the filamentous bacteriophage fl. Location of the A, C, and D minor coat proteins. $J$ Biol Chem. 256:539-46.

16. Holliger P, Riechmann L. 1997. A conserved infection pathway for filamentous bacteriophages is suggested by the structure of the membrane penetration domain of the minor coat protein $\mathrm{g} 3 \mathrm{p}$ from phage fd. Structure. 5:265-75.

17. Heilpern AJ, Waldor MK. 2003. pIIICTX, a predicted CTXphi minor coat protein, can expand the host range of coliphage fd to include Vibrio cholerae. J Bacteriol.

18. Lubkowski J, Hennecke F, Plückthun A, and Wlodawer A. 1999. Filamentous 185:1037-44.

20. Holliger P, Riechmann L, Williams RL. 1999. Crystal structure of the two Nterminal domains of $\mathrm{g} 3 \mathrm{p}$ from filamentous phage fd at $1.9 \mathrm{~A}$ : evidence for

19. Lubkowski J, Hennecke F, Plückthun A, Wlodawer A. 1998. The structural basis of phage display elucidated by the crystal structure of the N-terminal domains of g3p. Nature Struct Biol. 5:140 -7. 

The filamentous phages fd and IF1 use different mechanisms to infect Escherichia coli. J Mol Biol. 405:989-1003.

22. Ford CG, Kolappan S, Phan HT, Waldor MK, Winther-Larsen HC, Craig L. 2012. Crystal structures of a CTXphi pIII domain unbound and in complex with a Vibrio cholerae TolA domain reveal novel interaction interfaces. $J$ Biol Chem. 287:36258-72. on the outer membrane of the cell envelope. J Bacteriol. 115: 506-13.

24. Cavard, D, Lazdunski C. 1981. Involvement of BtuB and OmpF proteinsin binding and uptake of colicin A. FEMS Microbiol Lett. 12: 311-6.

25. Chai T, Wu V, Foulds J. 1982. Colicin A receptor: role of two Escherichia coli

26. Kurisu G, Zakharov SD, Zhalnina MV, Bano S, Eroukova VY, Rokitskaya TI, Antonenko YN, Wiener MC, Cramer WA. 2003. The structure of BtuB with bound colicin E3 R-domain implies a translocon. Nat Struct Biol. 10:948-54. 
27. Sharma O, Yamashita E, Zhalnina MV, Zakharov SD, Datsenko KA, Wanner BL, Cramer WA. 2007. Structure of the complex of the colicin E2 R-domain and its BtuB receptor. The outer membrane colicin translocon. J Biol Chem. 282:23163-70.

28. Zakharov, SD, Eroukova VY, Rokitskaya TI, Zhalnina MV, Sharma O, Loll PJ, Zgurskaya HI, Antonenko YN, Cramer WA. 2004. Colicin occlusion of OmpF and TolC channels: outer membrane translocons for colicin import. Biophys J. 87:

29. Yamashita E, Zhalnina MV, Zakharov SD, Sharma O, Cramer WA. 2008. Crystal structures of the OmpF porin: function in a colicin translocon. EMBO J. 27:

30. Housden, NG, Wojdyla JA, Korczynska J, Grishkovskaya I, Kirkpatrick N, Brzozowski AM, Kleanthous C. 2010. Directed epitope delivery across the Escherichia coli outer membrane through the porin OmpF. Proc Natl Acad Sci US

31. Housden NG, Hopper JT, Lukoyanova N, Rodriguez-Larrea D, Wojdyla JA, Klein A, Kaminska R, Bayley H, Saibil HR, Robinson CV, Kleanthous C. 2013. Intrinsically disordered protein threads through the bacterial outer-membrane porin OmpF. Science. 340: 1570-4.

32. Housden NG, Rassam P, Lee S, Samsudin F, Kaminska R, Sharp C, Goult JD, Francis ML, Khalid S, Bayley H, Kleanthous C. 2018. Directional Porin Binding 
of Intrinsically Disordered Protein Sequences Promotes Colicin Epitope Display in the Bacterial Periplasm. Biochemistry. 57:4374-81.

33. Deng LW, Perham RN. 2002. Delineating the site of interaction on the pIII protein of filamentous bacteriophage fd with the F-pilus of Escherichia coli. J Mol Biol. 319:603-14.

34. Martin A, Schmid FX. 2003. A proline switch controls folding and domain interactions in the gene-3-protein of the filamentous phage fd. J Mol Biol. 331:113140

371

35. Jacobson A. 1972. Role of F pili in the penetration of bacteriophage fl. $J$ Virol. 10:835-43.

36. Gao Y, Hauke CA, Marles JM, Taylor RK. 2016. Effects of tcpB mutations on biogenesis and function of TCP, the Type IVb pilus of Vibrio cholerae. J Bacteriol.

37. Ng D, Harn T, Altindal T, Kolappan S, Marles JM, Lala R, Spielman I, Gao Y, Hauke CA, Kovacikova G, Verjee Z, Taylor RK, Biais N, Craig L. 2016. The Vibrio cholerae Minor Pilin TcpB Initiates Assembly and Retraction of the ToxinCoregulated Pilus. PLoS Pathog. 12:e1006109. 
38. Russel M, Whirlow H, Sun TP, Webster RE. 1988. Low-frequency infection of Fbacteria by transducing particles of filamentous bacteriophages. $J$ Bacteriol. 170:5312-6.

39. Heilpern AJ, Waldor MK. 2000. CTXphi infection of Vibrio cholerae requires the tolQRA gene products. $J$ Bacteriol. 182:1739-47.

390

40. Sturgis JN. Organisation and evolution of the tol-pal gene cluster. 2001. J Mol Microbiol Biotechnol. 3:113-22.

41. Derouiche R, Bénédetti H, Lazzaroni JC, Lazdunski C, Lloubès R. 1995. Protein complex within Escherichia coli inner membrane. TolA N-terminal domain interacts with TolQ and TolR proteins. J Biol Chem. 270: 11078-84. its TolQ-interacting domain by genetic suppression. J Bacteriol. 180: 6433-9.

401

42. Germon, P, Clavel T, Vianney A, Portalier R, Lazzaroni JC. 1998. Mutational analysis of the Escherichia coli K-12 TolA N-terminal region and characterization of

43. Journet L, Rigal A, Lazdunski C, Bénédetti H. 1999. Role of TolR N-terminal, central, and C-terminal domains in dimerization and interaction with TolA and TolQ.

405 

7.

45. Bourdineaud JP, Howard SP, Lazdunski C. 1989. Localization and assembly into the Escherichia coli envelope of a protein required for entry of colicin A. J Bacteriol. 171: $2458-65$.

46. Kampfenkel K, Braun V. 1993. Membrane topologies of the TolQ and TolR proteins of Escherichia coli: inactivation of TolQ by a missense mutation in the proposed first transmembrane segment. J Bacteriol. 175: 4485-91.

418

47. Vianney A, Lewin TM, Beyer WF Jr, Lazzaroni JC, Portalier R, Webster RE. 1994. Membrane topology and mutational analysis of the TolQ protein of Escherichia coli required for the uptake of macromolecules and cell envelope integrity. J Bacteriol. 176: 822-9.

423

48. Levengood SK, Beyer WF Jr., Webster RE. 1991. TolA: a membrane protein involved in colicin uptake contains an extended helical region. Proc Natl Acad Sci U S A. 88: 5939-43. Bénédetti H. 1999. Structure of the Escherichia coli TolB protein determined by MAD methods at 1.95 A resolution. Structure. 7: 1291-300. 
50. Carr S, Penfold CN, Bamford V, James R, Hemmings AM. 2000. The structure of TolB, an essential component of the tol-dependent translocation system, and its protein-protein interaction with the translocation domain of colicin E9. Structure. 8:57-66.

51. Lazzaroni JC, Portalier R. 1992. The excC gene of Escherichia coli K-12 required for cell envelope integrity encodes the peptidoglycan-associated lipoprotein (PAL). Mol Microbiol. 6: 735-42.

52. Bouveret E, Bénédetti H, Rigal A, Loret E, Lazdunski C. 1999. In vitro characterization of peptidoglycan-associated lipoprotein (PAL)-peptidoglycan and PAL-TolB interactions. $J$ Bacteriol. 181: 6306-11.

53. Ray MC, Germon P, Vianney A, Portalier R, Lazzaroni JC. 2000. Identification by genetic suppression of Escherichia coli TolB residues important for TolB-Pal interaction. J Bacteriol. 182: 821-4.

\section{Cascales E, Bernadac A, Gavioli M, Lazzaroni JC, Lloubes R. 2002. Pal} lipoprotein of Escherichia coli plays a major role in outer membrane integrity. $J$ Bacteriol. 184:754-9.

55. Parsons LM, Lin F, Orban J. 2006. Peptidoglycan recognition by Pal, an outer membrane lipoprotein. Biochemistry. 45: 2122-8. 
56. Bouveret E, Derouiche R, Rigal A, Lloubès R, Lazdunski C, Bénédetti H. 1995. Peptidoglycan-associated lipoprotein-TolB interaction. A possible key to explaining the formation of contact sites between the inner and outer membranes of Escherichia coli. J Biol Chem. 270: 11071-7.

57. Cascales E, Gavioli M, Sturgis JN, Lloubès R. 2000. Proton motive force drives the interaction of the inner membrane TolA and outer membrane Pal proteins in Escherichia coli. Mol Microbiol. 38: 904-15.

58. Walburger A, Lazdunski C, Corda Y. 2002. The Tol/Pal system function requires an interaction between the C-terminal domain of TolA and the N-terminal domain of TolB. Mol Microbiol. 44: 695-708.

59. Dubuisson JF, Vianney A, Lazzaroni JC. 2002. Mutational analysis of the TolA Cterminal domain of Escherichia coli and genetic evidence for an interaction between TolA and TolB. J Bacteriol. 184: 4620-5.

60. Cascales E, Lloubès R. 2004. Deletion analyses of the peptidoglycan-associated lipoprotein Pal reveals three independent binding sequences including a TolA box. Mol Microbiol. 51:873-85.

61. Germon P, Ray MC, Vianney A, Lazzaroni JC. 2001. Energy-dependent conformational change in the TolA protein of Escherichia coli involves its Nterminal domain, TolQ, and TolR. J Bacteriol. 183:4110-4. 
62. Yeh YC, Comolli LR, Downing KH, Shapiro L, McAdams HH. 2010. The

482

483

484

485

486

487

488

489

490

491

492

493

494

495

496

497

498

499

500

501

502

503

504

505 caulobacter Tol-Pal complex is essential for outer membrane integrity and the positioning of a polar localization factor. J Bacteriol. 192: 4847-58.

63. Houot L, Navarro R, Nouailler M, Duché D, Guerlesquin F, Lloubes R. 2017. Electrostatic interactions between the CTX phage minor coat protein and the bacterial host receptor TolA drive the pathogenic conversion of Vibrio cholerae. $J$ Biol Chem. 292:13584-98 Erratum in: J Biol Chem. 2018, 293(19):7263

64. Gaspar JA, Thomas JA, Marolda CL, Valvano MA. 2000. Surface expression of O-specific lipopolysaccharide in Escherichia coli requires the function of the TolA protein. Mol Microbiol. 38:262-75.

65. Dennis JJ, Lafontaine ER, Sokol PA. 1996. Identification and characterization of the tolQRA genes of Pseudomonas aeruginosa. J Bacteriol. 178:7059-68.

66. Meury J, Devilliers G. 1999. Impairment of cell division in tolA mutants of Escherichia coli at low and high medium osmolarities. Biol Cell. 91:67-75.

67. Bernstein A, Rolfe B, Onodera K. 1972. Pleiotropic properties and genetic organization of the tolA,B locus of Escherichia coli K-12. J Bacteriol. 112: 74-83.

\section{Bernadac A, Gavioli M, Lazzaroni JC, Raina S, and Lloubès R. 1998.} Escherichia coli tol-pal mutants form outer membrane vesicles. J Bacteriol. 180:4872-8. 
69. Fognini-Lefebvre N, Lazzaroni JC, Portalier R. 1987. tolA, tolB and excC, three cistrons involved in the control of pleiotropic release of periplasmic proteins by Escherichia coli K12. Mol Gen Genet. 209: 391-5.

70. Lazzaroni JC, Portalier RC. 1981. Genetic and biochemical characterization of periplasmic-leaky mutants of Escherichia coli K-12. J Bacteriol. 145: 1351-8.

71. Prouty AM, Van Velkinburgh JC, Gunn JS. 2002. Salmonella enterica serovar typhimurium resistance to bile: identification and characterization of the tolQRA cluster. J Bacteriol. 184: 1270-6.

72. Shrivastava R, Jiang X, Chng SS. 2017. Outer membrane lipid homeostasis via retrograde phospholipid transport in Escherichia coli. Mol Microbiol. 106: 395-408.

73. Masilamani R, Cian MB, Dalebroux ZD. 2018. Salmonella Tol-Pal Reduces Outer Membrane Glycerophospholipid Levels for Envelope Homeostasis and Survival during Bacteremia. Infect Immun. 86:e0173-18.

74. Gerding MA, Ogata Y, Pecora ND, Niki H, de Boer PA. 2007. The trans-envelope 528 Tol-Pal complex is part of the cell division machinery and required for proper outermembrane invagination during cell constriction in E. coli. Mol Microbiol. 63: 1008- 
75. Bouveret E, Rigal A, Lazdunski C, Bénédetti H. 1997. The N-terminal domain of colicin E3 interacts with TolB which is involved in the colicin translocation step. Mol Microbiol. 23:909-20.

76. Bouveret E, Rigal A, Lazdunski C, Bénédetti H. 1998. Distinct regions of the colicin A translocation domain are involved in the interaction with TolA and TolB proteins upon import into Escherichia coli. Mol Microbiol. 27:143-57.

77. Loftus SR, Walker D, Maté MJ, Bonsor DA, James R, Moore GR, Kleanthous C. 2006. Competitive recruitment of the periplasmic translocation portal TolB by a natively disordered domain of colicin E9. Proc Natl Acad Sci U S A. 103:12353-8.

78. Sun TP, Webster RE. 1986. fii, a bacterial locus required for filamentous phage infection and its relation to colicin-tolerant tolA and tolB. $J$ Bacteriol. 165:107-15.

79. Bonsor DA, Grishkovskaya I, Dodson EJ, Kleanthous C. 2007. Molecular mimicry enables competitive recruitment by a natively disordered protein. $J \mathrm{Am}$ Chem Soc. 129 :4800-7.

80. Bonsor DA, Hecht O, Vankemmelbeke M, Sharma A, Krachler AM, Housden NG, Lilly KJ, James R, Moore GR, Kleanthous C. 2009. Allosteric beta-propeller signalling in TolB and its manipulation by translocating colicins. EMBO J. 28:284657. Erratum in: EMBO J. 28: 2858. 

reveals important differences in the recruitment of the common TolB translocation portal used by group A colicins. Mol Microbiol. 75:623-36.

82. Bénédetti H, Lazdunski C, and Lloubès R. 1991. Protein import into Escherichia coli: colicins A and E1 interact with a component of their translocation system. EMBO J. 10:1989-95.

83. Derouiche R, Zeder-Lutz G, Bénédetti H, Gavioli M, Rigal A, Lazdunski C, Lloubès R. 1997. Binding of colicins A and El to purified TolA domains. Microbiology. 143:3185-92.

84. Raggett EM, Bainbridge G, Evans LJ, Cooper A, Lakey JH. 1998. Discovery of critical Tol A-binding residues in the bactericidal toxin colicin N: a biophysical approach. Mol Microbiol. 28:1335-43.

570

85. Barnéoud-Arnoulet A, Gavioli M, Lloubès R, and Cascales E. 2010. Interaction of the colicin $\mathrm{K}$ bactericidal toxin with components of its import machinery in the periplasm of Escherichia coli. J Bacteriol. 192:5934-42.

86. Click EM, Webster RE. 1997. Filamentous phage infection: required interactions with the TolA protein. J Bacteriol. 179:6464-71. 
88. Karlsson F, Borrebaeck CA, Nilsson N, Malmborg-Hager AC. 2003. The mechanism of bacterial infection by filamentous phages involves molecular interactions between TolA and phage protein 3 domains. J Bacteriol. 185:2628-34.

584

89. Schendel SL, Click EM, Webster RE, Cramer WA. 1997. The TolA protein interacts with colicin E1 differently than with other group A colicins. J Bacteriol. 179:3683-90.

90. Anderluh G, Gökçe I, and Lakey JH. 2004. A natively unfolded toxin domain uses its receptor as a folding template. J Biol Chem. 279:22002-9.

91. Li C, Zhang Y, Vankemmelbeke M, Hecht O, Aleanizy FS, Macdonald C, Moore G.R, James R, Penfold CN. 2012. Structural evidence that colicin A protein binds to a novel binding site of TolA protein in Escherichia coli periplasm. J Biol Chem. 287:19048-57.

92. Hecht O, Ridley H, Lakey JH, Moore GR. 2009. A common interaction for the entry of colicin N and filamentous phage into Escherichia coli. J Mol Biol. 388: 88093.

600

93. Ridley H, Lakey JH. 2015. Antibacterial toxin colicin N and phage protein G3p compete with TolB for a binding site on TolA. Microbiology. 161: 503-15. 
94. Sun TP, Webster RE. 1987. Nucleotide sequence of a gene cluster involved in entry of colicins and single-stranded DNA of infecting filamentous bacteriophages into Escherichia coli. J. Bacteriol. 169: 2667-74.

95. Journet L, Bouveret E, Rigal A, Lloubes R, Lazdunski C, Bénédetti H. 2001. Import of colicins across the outer membrane of Escherichia coli involves multiple protein interactions in the periplasm. Mol Microbiol. 42:331-44.

96. Duché D, Letellier L, Géli V, Bénédetti H, Baty D. 1995. Quantification of group A colicin import sites. J Bacteriol. 177:4935-9.

97. Duché D. 2007. Colicin E2 is still in contact with its receptor and import machinery when its nuclease domain enters the cytoplasm. J Bacteriol. 189:4217-22.

98. Bénédetti H, Lloubès R, Lazdunski C, Letellier L. 1992. Colicin A unfolds during its translocation in Escherichia coli cells and spans the whole cell envelope when its pore has formed. EMBOJ. 11:441-7.

99. Duché D, Baty D, Chartier M, Letellier L. 1994. Unfolding of colicin A during its translocation through the Escherichia coli envelope as demonstrated by disulfide bond engineering. J Biol Chem. 269:24820-5.

100. Griko YV, Zakharov SD, Cramer WA. 2000. Structural stability and domain organization of colicin E1. J Mol Biol. 302:941-53. 
101. Housden NG, Loftus SR, Moore GR, James R, Kleanthous C. 2005. Cell entry mechanism of enzymatic bacterial colicins: porin recruitment and the thermodynamics of receptor binding. Proc Natl Acad Sci U S A. 102:13849-54.

102. Bennett NJ, Rakonjac J. 2006. Unlocking of the filamentous bacteriophage virion during infection is mediated by the C domain of pIII. $J$ Mol Biol. 356:266-73.

634

103. Glaser-Wuttke, G, Keppner J, Rasched I. 1989. Pore-forming properties of the adsorption protein of filamentous phage fd. Biochim Biophys. Acta 985:239-47

637 of Escherichia coli. J Bacteriol. 142:162-8.

640

105. Bourdineaud JP, Boulanger P, Lazdunski C, Letellier L. 1990. In vivo properties of colicin A: channel activity is voltage dependent but translocation may be voltage independent. Proc Natl Acad Sci U S A. 87:1037-41.

644

106. Goemaere EL, Cascales E, Lloubès R. 2007. Mutational analyses define helix organization and key residues of a bacterial membrane energy-transducing complex.

107. Lloubès R, Goemaere E, Zhang X, Cascales E, Duché D. 2012. Energetics of colicin import revealed by genetic cross-complementation between the Tol and Ton systems. Biochem Soc Trans. 40:1480-5. 
108. Duché D, Frenkian A, Prima V, Lloubès R. 2006. Release of immunity protein requires functional endonuclease colicin import machinery. J Bacteriol. 188:8593-

655 600.

656

109. Vankemmelbeke M, Zhang Y, Moore GR, Kleanthous C, Penfold CN, James R. 2009. Energy-dependent immunity protein release during tol-dependent nuclease colicin translocation. J Biol Chem. 284:18932-41.

660

110. Yamamoto M, Kanegasaki S, Yoshikawa M. 1981. Role of membrane potential and ATP in complex formation between Escherichia coli male cells and filamentous phage fd. J Gen Microbiol. 123:343-9.

664

665

666

667 227:65-71

668

112. Johnson CL, Ridley H, Marchetti R, Silipo A, Griffin DC, Crawford L, Bonev B, Molinaro A, Lakey JH. 2014. The antibacterial toxin colicin N binds to the inner core of lipopolysaccharide and close to its translocator protein. Mol Microbiol.

673

113. Bradley DE, Howard SP. 1992. A new colicin that adsorbs to outer-membrane protein Tsx but is dependent on the tonB instead of the tolQ membrane transport system. J Gen Microbiol. 138: 2721-4. 
114. Smajs D, Pilsl H, Braun V. 1997. Colicin U, a novel colicin produced by Shigella boydii. J Bacteriol. 179: 4919-28.

115. Jakob RP, Geitner AJ, Weininger U, Balbach J, Dobbek H, Schmid FX. 2012. Structural and energetic basis of infection by the filamentous bacteriophage IKe. $\mathrm{Mol}$ Microbiol. 84:1124-38.

116. Campos J, Martínez E, Suzarte E, Rodríguez BL, Marrero K, Silva Y, Ledón T, del Sol R, Fando R. 2003. VGJ phi, a novel filamentous phage of Vibrio cholerae, integrates into the same chromosomal site as CTX phi. J Bacteriol. 185:5685-96.

117. Holland SJ, Sanz C, Perham RN. 2006. Identification and specificity of pilus adsorption proteins of filamentous bacteriophages infecting Pseudomonas aeruginosa. Virology. 345:540-8

118. Baboolal TG, Conroy MJ, Gill K, Ridley H, Visudtiphole V, Bullough PA, Lakey JH. 2008. Colicin N binds to the periphery of its receptor and translocator, outer membrane protein F. Structure. 2008 16: 371-9.

119. Lakey JH, Slatin SL. 2001. Pore-forming colicins and their relatives. Curr Top Microbiol Immunol. 257: 131-61.

120. Walker D, Mosbahi K, Vankemmelbeke M, James R, Kleanthous C. 2007. The role of electrostatics in colicin nuclease domain translocation into bacterial cells. $J$ Biol Chem. 282:31389-97 
121. Chauleau M, Mora L, Serba J, de Zamaroczy M. 2011. FtsH-dependent processing of RNase colicins D and E3 means that only the cytotoxic domains are imported into the cytoplasm. J Biol Chem. 286: 29397-407.

707

708

122. Mosbahi K, Lemaître C, Keeble AH, Mobasheri H, Morel B, James R, Moore

709

GR, Lea EJ, Kleanthous C. 2002. The cytotoxic domain of colicin E9 is a channel-

710 forming endonuclease. Nat Struct Biol. 9:476-84.

711

712 
713 Table1. Host proteins required for reception and translocation of filamentous phages and group A colicins.

714

715

Name

716

717

718 Group A colicins

719

720

ColA

BtuB

$\mathrm{OmpF}$

TolA, B, Q, R

Pore-forming

721

ColE2, E7, E8, E9

BtuB

$\mathrm{OmpF}$

TolA, B, Q, R

Dnase

722 ColE3, E4, E6

BtuB

$\mathrm{OmpF}$

TolA, B, Q, R

rRNase

723 ColE1

BtuB

TolC

TolA, Q

Pore-forming

724 ColN

LPS

$\mathrm{OmpF}$

TolA, Q, R

Pore-forming

725 ColE5

BtuB

$\mathrm{OmpF}$

TolA, B, Q, R

tRNase

726 ColK

Tsx

OmpF/OmpA

TolA, B, Q, R

Pore-forming

727 ColU

OmpA

$\mathrm{OmpF}$

TolA, B, Q, R

Pore-forming

728

729

\section{Filamentous phages}

730

Ff (Fd, f1, M13)

F-pilus

TolA, Q, R

E. coli

731 IKE

N-pilus

TolA, Q, R

E. coli

732 IF1

I-pilus

n.d.

E.coli

733 CTX

TCP pilus

TolA, Q, R

V. cholerae

734 VGJ

MshA pilus

n.d.

V. cholerae

735 Pf1

type IV PAK pilus

n.d.

P. aeruginosa

$736 \quad$ Pf3

RP4 pilus

n.d.

P. aeruginosa

737

Only references that do not appear in the text are cited in this table. n.d.: not determined. 
Figure 1. Colicin and phage minor coat protein organization and crystal structures. (A)

742

743

744

745

746

747

748

749

750

751

752

753

754

755

756

757

758

759

760

761

762

763

764

Schematic representation highlighting the similar general organization of colicin and phage pIII proteins for Translocation ( $\mathrm{T}$ or N1 domains), Reception (R or N2 domains), and Activity or Anchoring (A or C domain), respectively. (B) Structures of: full length colicin E3 (top left, PDB: 1JCH) bound to its immunity protein (in green); full length colicin N (top right, PDB: 1A87); M13 phage protein pIII N1-N2 domains (bottom left, PDB: 1G3P); and superposition (bottom right) of E. coli TolAIII domain (grey) interacting with the colicin A T-domain on its convex side (co-crystal PDB: 3QDR) and E. coli TolAIII domain (grey) interacting with G3PN1 on its concave side (co-crystal PDB: 1TOL). The color code used for each protein domain is the same for panels A and B.

\section{Figure 2. Models of group A colicin (A) and Tol-dependent filamentous phage import (B)}

into sensitive $\boldsymbol{E}$. coli cells. (A) In stage 1, colicin binds to the OM receptor by its central domain $(26,27)$. In stage 2(a), the disordered $\mathrm{N}$-terminal segment of the T-domain translocates through the OM ß-barrel and interacts with a free periplasmic TolB or dissociates TolB from Pal (28$31,77,79,81)$. In stage 2(b), the N-terminal segment interacts with other Tol proteins (82-85, 95). At this stage, the immunity protein of nuclease colicins is released $(108,109)$. Then, the unfolded C-terminal domain is thought to cross the OM through the interface between OmpF and the lipid bilayers (118) or directly through the OmpF porin (28). In stage 3, for pore-forming colicins $(i)$ the C-terminal domain inserts spontaneously into the IM and form voltage-gated channels that depolarize and kill the target bacteria (for a review see, 119). For nuclease colicins (ii), the C-terminal domain is cleaved by FtsH $(120,121)$, an essential ATP-dependent IM protease, and spontaneously crosses the IM (122) or uses FtsH for its transfer (121). (B) In stage 
765 1, the phage minor coat protein pIII-N2 domain binds to the tip of a F-pilus protruding from the

766 cell surface (33). In stage 2, pilus retraction pulls the phage into the cell periplasm, possibly

767 through the pilus secretin pore. Once there, the phage pIII-N1 domain interacts with the

768 globular domain of TolA (TolAIII) $(86,87)$. In E. coli, a direct interaction between TolAII and

769 phage pIII-N2 has been reported (dash arrow) (88). The PMF-dependent TolQR motor may

770 trigger conformational changes of TolA that brings the phage particle in close contact with the

771 IM. The phage uncapping process during the uptake stage (3) is speculative. In the model, pIII

772 oligomerizes to form a channel in the IM of the host through its C-ter domain (pIII-C). Then,

773 diffusion of the phage pVIII major coat protein in the IM leads to disassembly of the capsid,

774 releasing the internal pressure of the structure. This force is thought to drive phage DNA

775 injection through the IM pIII-C channel $(102,103)$.

776 OM, outer membrane; IM, inner membrane; PG, peptidoglycan; peri, periplasm; cyto,

777 cytoplasm; rec, receptor; trans, translocator. The phage is composed of three to five copies of

778 pIII, but only one copy has been represented, and other minor virion coat proteins have been

779 omitted for simplicity. 
A

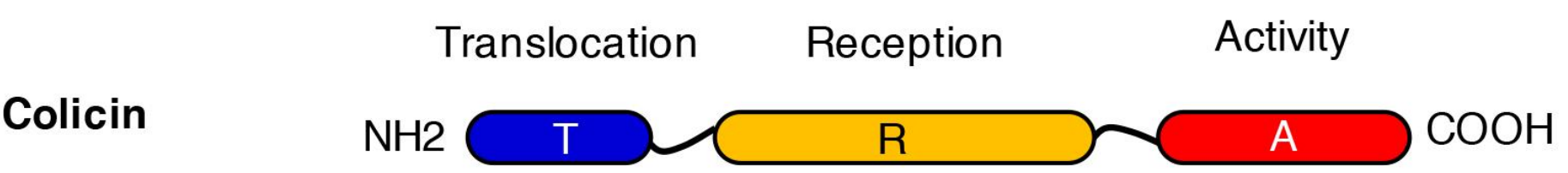

Phage

Translocation Reception Anchoring

protein plll

$\mathrm{NH} 2$

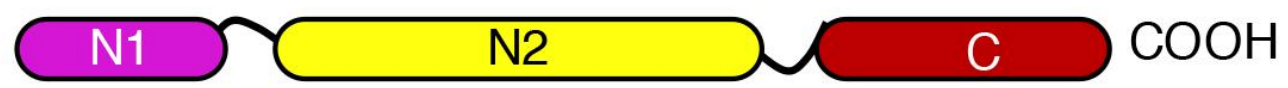

B
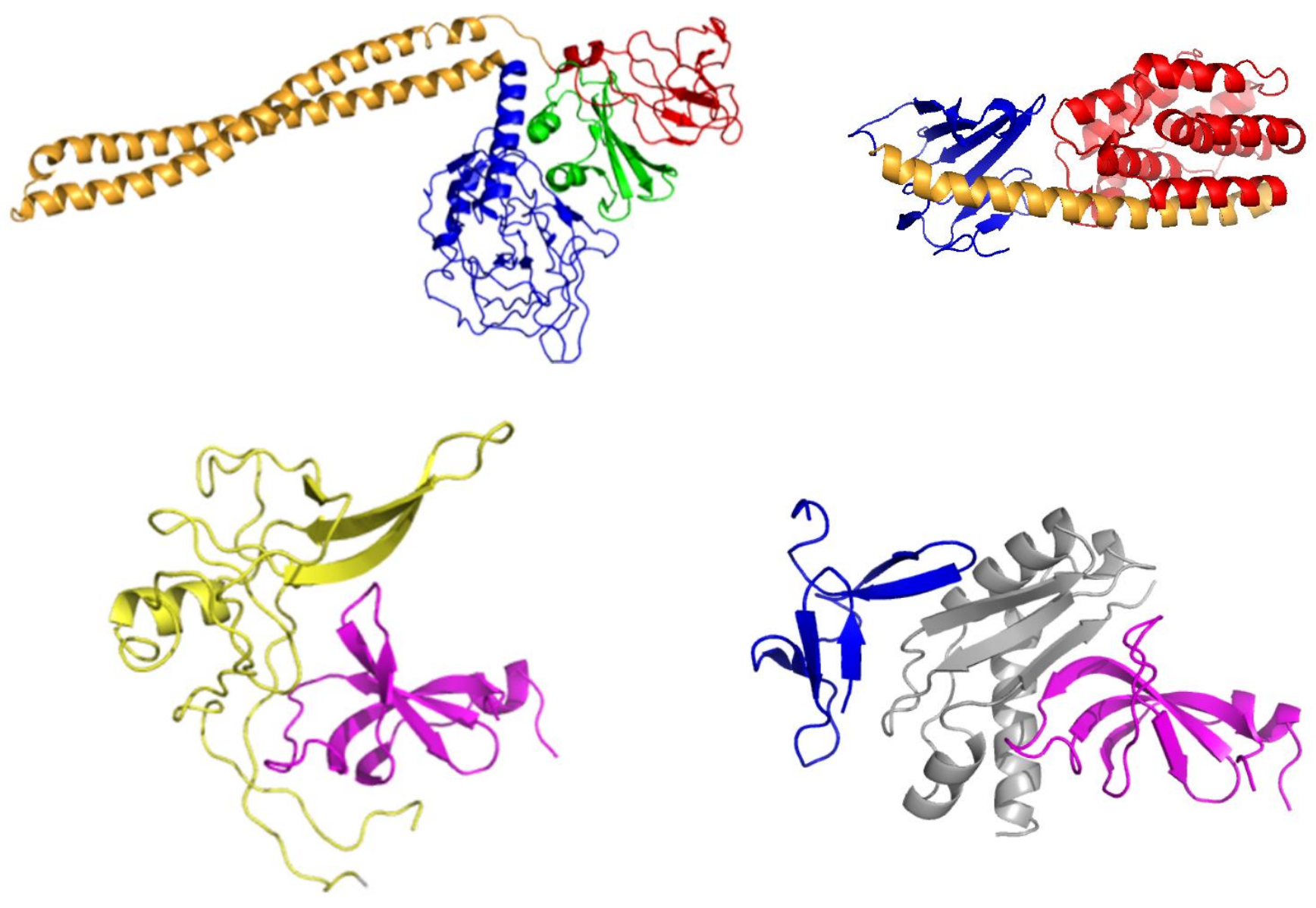
A

1. Reception

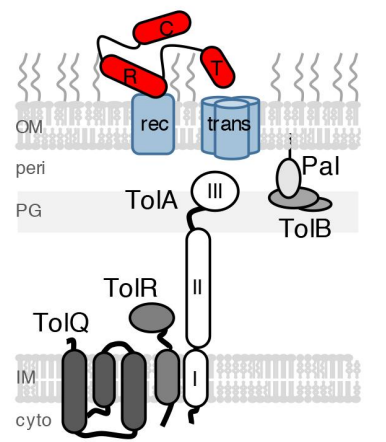

B
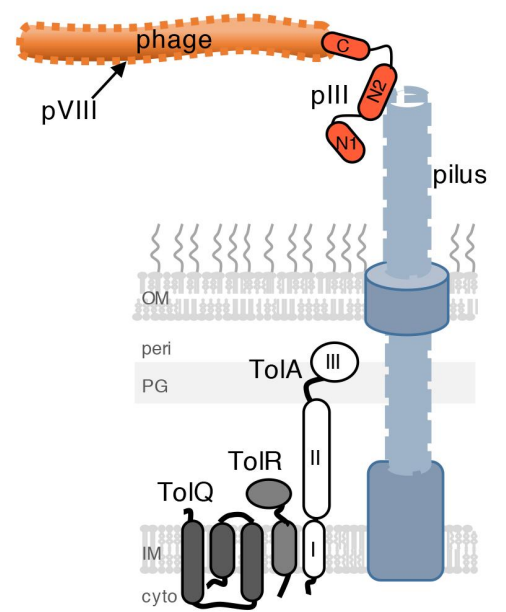

2. Translocation

(b)

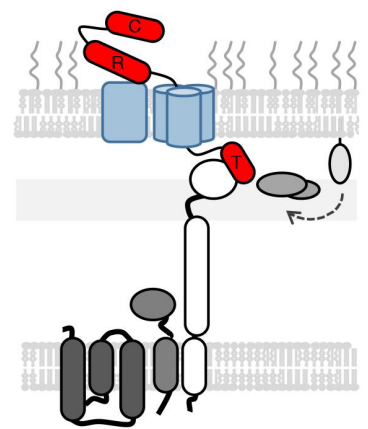

2. Translocation

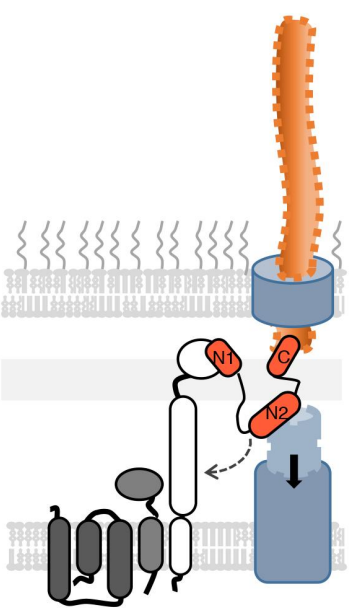

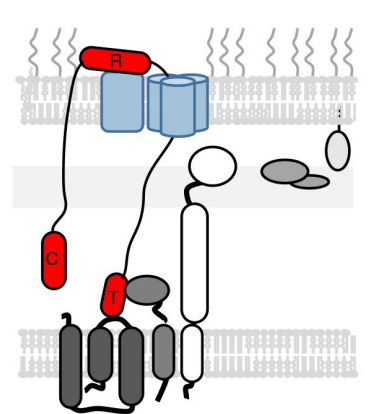

3. Uptake

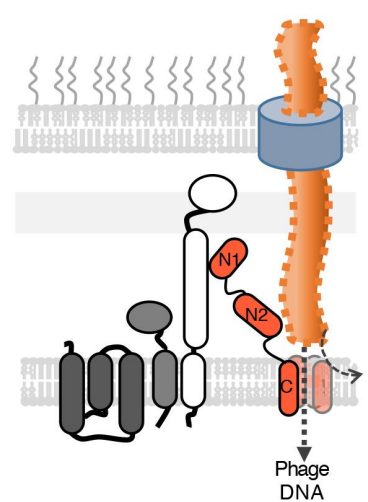

3. Activity

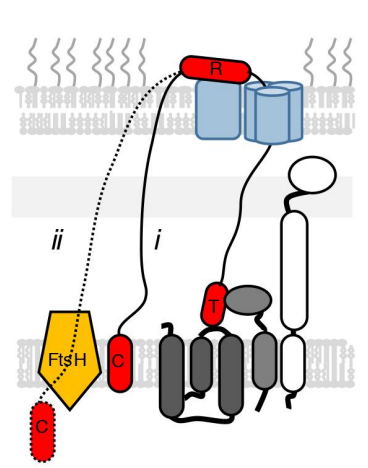

Figure: 2 